\title{
Papillary villoglandular carcinoma of cervix with multiple HPV genome
}

\section{Serviksin multipl HPV genomu bulunduran papiller villoglandüler adenokarsinomu}

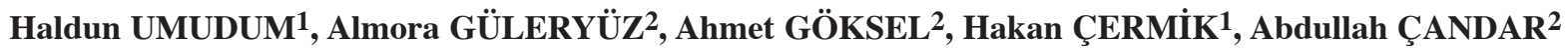 \\ Etimesgut Asker Hastanesi, Patoloji Bölümü̈ ${ }^{1}$, Kadın Doğum Kliniğ i² ${ }^{2}$ ANKARA
}

\begin{abstract}
We report a case of well differentiated villoglandular adenocarcinoma with adenocarcinoma in situ component. Patient was an asymptomatic premenopausal woman, which was referred with atypical glandular cells of undetermined significance (AGUS) diagnosis established with cervicovaginal smear. Chromogenic in situ hybridization showed the presence of dual HPV (subtype 16/18 and 31/33) genomes. P53 overexpression and increased $\mathrm{Ki} 67$ expression were detected on both invasive and in situ component. No evidence of disease was detected sixty-five months after staging laparotomy. This case is an uncommon example of multiple HPV infections leading to unusual cervical tumor.
\end{abstract}

Key words: Papillary villoglandular adenocarcinoma, multipl HPV genome, chromogenic in situ hybridization, adenocarcinoma in situ

\section{INTRODUCTION}

Well differentiated villoglandular adenocarcinoma (VGA) of the cervix is a curious subtype of cervical adenocarcinoma (CA). This neoplasm is relatively new in gynecological pathology; first description of VGA was in 1989 by Young and Scully (1). Clinicopathological features of VGA were documented in 1993 and it was accepted as a distinct subtype in the 1994WHO classification (2). VGA is characterized

Received: 28.05 .2008

Accepted: 25.09.2008

Corresponding Author: Dr. Haldun Umudum, Etimesgut Asker Hastanesi, Patoloji, Ankara

\section{ÖZET}

Bu sunumda adenokarsinoma in situ komponenti bulunan iyi diferansiye villoglanduler adenokarsinom olgusunu bildiriyoruz. Hasta servikovajinal yaymasında önemi belirsiz atipik endoservikal hücreler (AGUS) tanısı ile incelenen asemptomatik premenapozal kadınd. Hastanın ikinci muayenesinde saptanan serviksteki papiller lezyon eksize edildi. Histopatolojik inceleme lezyonun adenokarsinoma in situ komponenti olan iyi diferansiye villoglanduler karsinom olduğunu gösterdi. Kromojenik in situ hibridizasyon lezyonda iki farklı tipte HPV (16/18 ve 31/33 subtipleri) genomunun bulunduğunu ortaya koydu. İnvaziv ve non invaziv komponentlerde p53 ve artmış Ki 67 ekspresyonu saptadık. Hasta evreleme laparatomisinden 65 ay sonra hastalıksız olarak hayattadır. Bu olgu multipl HPV infeksiyonunun nadir görülen servikal bir maligniteye ilerlediğini gösteren istisnai bir örnektir.

Anahtar sözcükler: Papiller villoglanduler adenokarsinom, multipl HPV genomu, kromojenik in situ hibridizasyon, adenokarsinoma in situ

by specific papillary morphology and favorable prognosis.

Whereas the pathogenesis of cervical squamous cell carcinoma is linked to infection with oncogenic types of human papillomavirus (HPV), the factors contributing to the pathogenesis of CA are less understood. Although HPV DNA is commonly detected in most squamous cell carcinomas (>90\%), the reported prevalence of HPV DNA in CA varies from $32 \%$ to $100 \%$, depending on the detection method used $(3,4)$. We hereby report a case of VGA, of which both in situ and invasive components expressed multiple high-risk HPV types in chromogenic in situ hybridization (ISH). 


\section{CASE REPORT}

Forty three- year- old female patient had been admitted to gynecology outpatient clinic for her routine annual examination. Her medical history was unremarkable and she had no medical complaints. On her first admission no abnormality was found on physical examination. A conventional Pap smear had been taken. Pap smear was reported as "atypical endocervical cells probably neoplastic". She was admitted into clinic three months after initial examination. On second admission, an exophytic lesion was detected on gynecologic examination and the lesion was excised with Loop Electrosurgical Excision Procedure (LEEP). Gross examination of LEEP material displayed a white dome shaped papillary lesion in $1 \mathrm{~cm}$ diameter, which was closer to lateral surgical margin. Histopathological evaluation of LEEP material showed an exophytic lesion formed of large papillae and infiltrative tumor in the cervical stroma (Fig 1a). The papillae in the exophytic lesion were formed of fibrovascular cores lined with intestinal type epithelial cells displaying mild nuclear atypia and nuclear pseudostratification (Fig 1b). The subepithelial component was composed of infiltrative cribriform glands surrounded with desmoplastic stroma. Adjacent to subepithelial tumor, there were endocervical glands lined with both cytologically atypical and normal endocervical cells. The cervical squamous epithelium showed no evidence of intraepithelial lesion.

This lesion was reported as "well differentiated villoglandular adenocarcinoma with

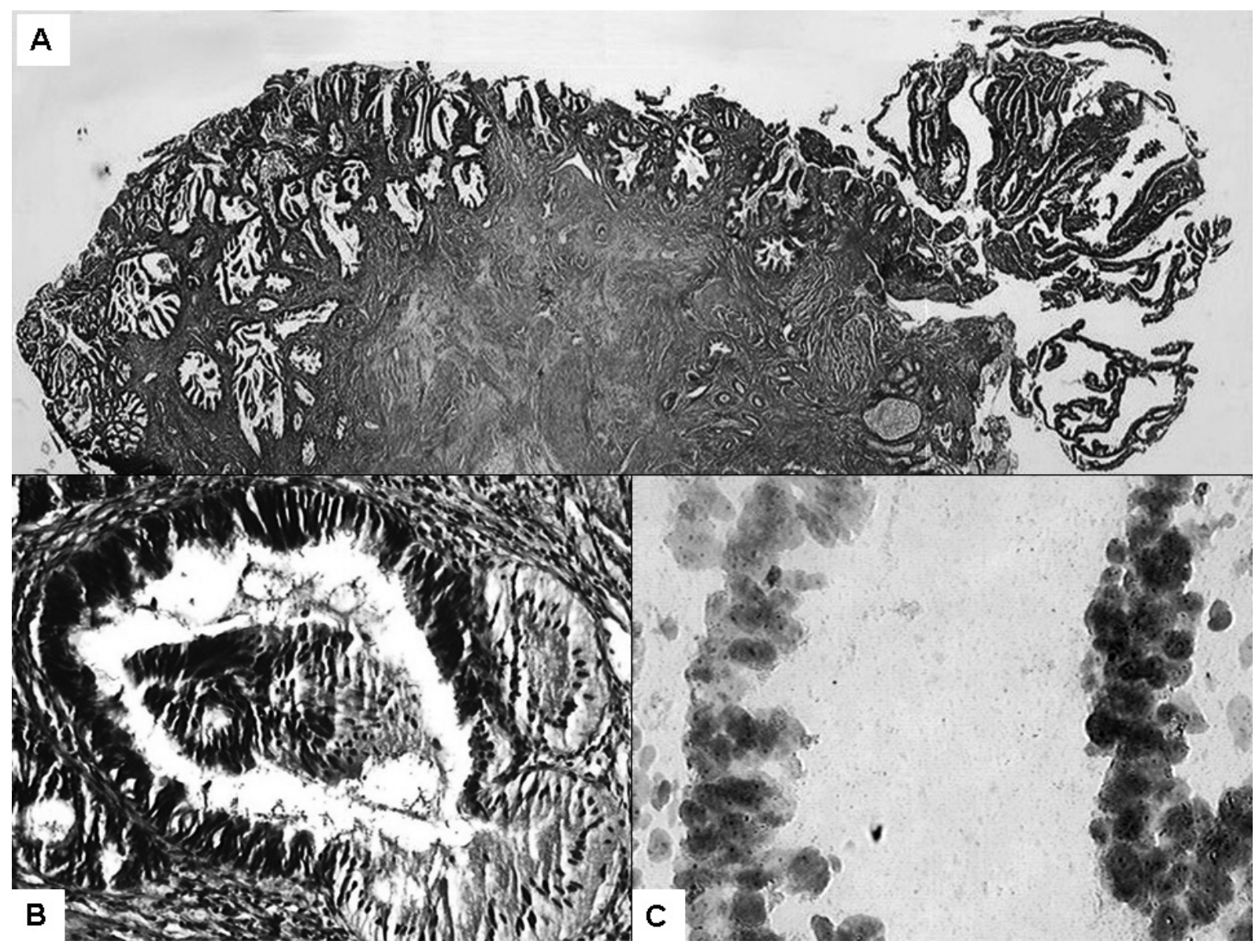

Figure. 1a. Whole mount view of cervical exophytic tumor, 1b. Adenocarcinoma in situ. Precursor lesion of invasive adenocarcinoma. Normal endocervical cells and cytologically atypical cells line the same gland, 1c. Chromogenic in situ hybridization (HPV 31-33). Black dots on cell nuclei denote a positive signal. 
multiple foci of endocervical carcinoma in situ. Largest diameter of tumor is $1 \mathrm{~cm}$ (including exophytic component). There is no squamous cell abnormality in adjacent cervical epithelium. Tumor is observed in deep and lateral surgical margins". Patient was referred to another institution and she underwent a total abdominal hysterectomy with surgical staging. Histopathological evaluation of the staging laparatomy material revealed only a microscopic residual tumor in the endocervical canal. Lymph nodes were free of tumor. Patient is well and no evidence of disease is detected sixty-four months after laparatomy.

\section{In situ hybridization (ISH):}

Chromogenic ISH test was done using following probes: wide spectrum HPV DNA (6, 11, 16, 18, 31, 33, 35, 45, 51, and 52.), HPV DNA 16/18 and HPV DNA 31/33 (Dako Corporation, Denmark). Protocol for chromogenic in situ hybridization (CISH) was described elsewhere. In this method, a blue-purple reaction specifically located on tumor cell nuclei was interpreted as a positive test result (Fig1c). A wide spectrum mucosotrophic HPV DNA, HPV 16/18 and 31/33 were detected on both VGA and AIC. There was no evidence of reactivity in non-neoplastic cervical or endocervical tissue.

P53 and Ki67 overexpression were also observed in both VGA and AIC areas.

\section{DISCUSSION}

Villoglandular adenocarcinoma is characterized by a superficial and an invasive component. Superficial component, which is composed of papillae, protrudes from cervical surface. Infiltrative component that is located in subepithelial areas, is formed of branching irregular glands and surrounded with desmoplastic stroma. Nuclear atypia and pleomorphism are of mild to moderate degree and mitotic activity is low. By definition, profuse cellular branching, highly pleomorphic nuclei and high mitotic acti- vity are not supposed to be present. These findings are consistent with aggressive papillary serous carcinoma, which is a potentially fatal lesion in contrast to favorable outcome associated with VGA (4).

In addition to papillary and invasive components, a precursor lesion i.e. adenocarcinoma in situ (AIS) is usually found around invasive tumor. AIS has been characterized with certain features in that glandular architecture is conserved but glandular lining is partly replaced by epithelial cells showing pseudostratification and mild nuclear atypia. Cytoplasmic mucin production is altered; either reduced or increased abundantly. In the present case, AIS foci were noted in the glands adjacent to the infiltrative component of VGA. Jones et al. noted the presence of AIS in 8 cases of VGA (5). Partial involvement of the glands by malignant cells and absence of desmoplastic response are the histopathological features, which distinguish AIS from individual malignant glands (6). Although desmoplastic stroma is evident around infiltrative tumor, we did not observe desmoplastic stroma around the AIS foci (6).

In this case we were able to identify HPV 16-18 and HPV 31-33 types in VGA and also in AIS component. Although multiple HPV DNA subtypes were commonly found in squamous cell carcinomas of cervix, detection of multiple subtypes in endocervical adenocarcinoma without squamous lesion has been stated as exceptional (7).

Prevalence of HPV DNA in CA is dependent on histological type of the tumor. HPV DNA has been detected in almost all mucinous CAs (8). Multiple HPV subtypes were found in 5 out of 21 AIS and in 8 out of 80 invasive and in situ adenocarcinomas combined (8). A recent study in Korean women showed multiple infections in 13\% (18/135 cases) of all invasive adenocarcinomas. HPV 16 is the most predominant type in cases with multiple and single infection. In this study, only one out of 5 VGAs was found to have multiple HPV types 
(16 and 18) whereas the rest had single HPV type (9). Mathhews-Greer et al. noted infection with multiple subtypes in different histological subtypes. They found one VGA with HPV 16 and 52 subtype infection. HPV 16 is the predominant type in all multiple and single infections in CA (10).

In accordance with our observation in this case, multiple HPV infections are often associated with those viruses belonging to the same clade. HPV-16, HPV-31, and HPV-33 all belong to the A9 clade (11). Thomas et al. evaluated whether the prior infection with specific HPV types inhibits subsequent infection by related types and they found that concurrent acquisition of multiple types occurred more often than expected (12).

After its first description in 1953, AIS has been evaluated in many studies for putative precursor lesion of CA. Sufficient evidence is available for AIS as a precursor lesion of CA $(13,14)$. Besides histological and demographic data, similar HPV types are found in both AIS and invasive adenocarcinoma. In addition to observing same HPV subtypes, AIS foci in the present case also displayed p53 overexpression and increased Ki67 expression. These findings support the hypothesis that AIS is also a precursor lesion associated with VGA.

\section{REFERENCES}

1. Young RH, Scully RE. Villoglandular adenocarcinoma of the uterine cervix. Cancer 1989;63:1773-1779.
2. Jones MW, Silverberg SG, Kurman RJ. Well-differentiated villoglandular adenocarcinoma of the uterine cervix: a clinicopathological study of 24 cases. Int J Gynecol Pathol 1993;12:1-7.

3. Duggan MA, McGregor SE, Benoit JL. The human papillomavirus status of invasive cervical adenocarcinoma: a clinicopathological and outcome analysis. Hum Pathol 1995;26:319-325.

4. Young RH, Clement PB. Endocervical adenocarcinoma and its variants: their morphology and differential diagnosis. Histopathology 2002;41:185-207.

5. Jones MW, Kounelis S, Papadaki H. Well-Differentiated villoglandular adenocarcinoma of the uterine cervix: Oncogene/Tumor Suppressor Gene alterations and human papillomavirus genotyping. Int J Gynecol Pathol 2000;19:110-117.

6. Zaino RJ. Glandular lesions of the uterine cervix. Mod Pathol 2000;13:261-274.

7. Huang LW, Chao SL, Chen PH, Chou HP. Multiple HPV genotypes in cervical carcinomas: improved DNA detection and typing in archival tissues. J Clin Virol 2004;29:271-276.

8. Pirog EC, Kleter B, Olgac S. Prevalence of human papillomavirus DNA in different histological subtypes of cervical adenocarcinoma. Am J Pathol 2000;157: 1055-1062.

9. An HJ, Kim KR, Kim IS. Prevalence of human papillomavirus DNA in various histological subtypes of cervical adenocarcinoma: a population-based study. Mod Pathol 2005;18:528-534.

10. Matthews-Greer J, Dominguez-Malagon H, Herrera GA. Human papillomavirus typing of rare cervical carcinomas. Arch Pathol Lab Med 2004;128:553-556.

11. Liaw K-L, Hildesheim A, Burk RD. A prospective study of human papillomavirus (HPV) type 16 DNA detection by polymerase chain reaction and its association with acquisition and persistence of other HPV types. J Infect Dis 2000;183:8-15.

12. Thomas KK, Hughes JP. Concurrent and sequential acquisition of different genital human papillomavirus types. J Infect Dis 2000;182:1097-1102.

13. Friedell G, McKay D. Adenocarcinoma in situ of the endocervix. Cancer 1953;6:887-897.

14. Christopherson W, Nealon N, Gray L. Noninvasive precursor lesions of adenocarcinoma and mixed adenosquamous carcinoma of the cervix uteri. Cancer 1979;44:975-983. 